\title{
PREFERENSI PETANI DALAM PENJUALAN GABAH PASCA PANEN DI DESA SUMUR MATI KECAMATAN SUMBERASIH KABUPATEN PROBOLINGGO
}

\author{
Musyarofah $^{1}$, Pudjo Suharso ${ }^{1}$, Titin Kartini ${ }^{1}$ \\ ${ }^{1}$ Program Studi Pendidikan Ekonomi, Fakultas Keguruan dan Ilmu Pendidikan, Universitas Jember
}

\begin{abstract}
This research was conducted to describe farmer preference in post-harvest grain sales and to know the working relationship of farmers with Bulog, middlemen and market kiosk traders. The type of this research is descriptive with qualitative approach. The method of determining the location of research using the method of purposive area is in the Sumur Mati Village Sumberasih District Probolinggo. The main informants in this study were 12 rice farmers, with the criteria of ever selling grain more than 5 times. While the additional informants in this study are Bulog Officials, Brokers, and Kiosk Traders. Data collection methods used consisted of methods: interviews, observation, and documents. Data analysis used is descriptive analysis which include data reduction, data presentation, and conclusion (verification). The results showed that Farmers' preferences in the Sumur Village died based on experience gained and trust decreased. Farmers in Sumur Mati Village sell grain to Bulog, middlemen, and market stall traders. Bulog's relationship with farmers is a partnership. The partnership between Bulog and the farmers did not last long because the farmers felt the loss. The relationship between middlemen and farmers is intertwined in a patron-client bond. A middleman as a patron takes a strategic role in this client's patron relationship by lending money to farmers or clients to meet initial capital requirements. While the relationship between market stall traders with farmers is the relationship between agents and actors as in the theory of Giddens structure. Where the relationship between buying and selling kiosk vendors with farmers in this study also occurs continuously and in it there are social practices. Farmers and traders established contractual relationship.
\end{abstract}

Keywords: Farmers 'Preferences in Sales Of Post-Harvest Costs

\section{PENDAHULUAN}

Petani menanam padi selain memenuhi kebutuhan untuk dikonsumsi, juga sebagai mata pencaharian dengan menjual hasil panen yang didapatnya. Pemasaran merupakan hal yang penting dalam menjalankan usaha pertanian karena pemasaran merupakan kegiatan ekonomi yang berpengaruh terhadap tinggi rendahnya pendapatan petani. Dalam penjualan hasil panen padi, petani memiliki beberapa preferensi yaitu kepada Perum Bulog, tengkulak, dan pasar. Preferensi seorang petani akan berbeda dengan preferensi petani lainnya. Dengan kata lain preferensi petani berarti subjektif. Perbedaan ini disebabkan banyak faktor seperti lingkungan sosial, geografis, suku bangsa, jenis kelamin, status, umur dan sebagainya (Wiranto, 1992).

Perusahaan Umum Badan Urusan Logistik (Perum Bulog) merupakan sebuah lembaga pangan di Indonesia yang mengurusi tata niaga beras. Sesuai dengan Instruksi Presiden Republik Indonesia No. 5 Tahun 2015 Tentang Kebijakan Pengadaan Gabah/Beras dan Penyaluran Beras oleh Pemerintah, Bulog mengutamakan pengadaan beras/gabah yang berasal dari pembelian gabah/beras petani dalam negeri. Dalam proses pembelian, Bulog tidak langsung membeli gabah/beras dari petani melainkan melalui kelompok tani disetiap daerah. Bulog melakukan pengadaan dan penyaluran gabah/beras melalui pembelian dalam negeri dengan ketentuan harga pembelian pemerintah. Dalam pembelian gabah/beras dalam negeri, Bulog melakukan kerjasama dengan petani melalui kelompok tani. Hubungan kerjasama antara Bulog dengan mitra tani yaitu kemitraan. Menurut Sulistiyani (2004: 129), kemitraan adalah suatu bentuk persekutuan antara dua pihak atau lebih yang membentuk suatu ikatan kerjasama 
atas dasar kesepakatan dan rasa saling membutuhkan dalam rangka meningkatkan kapasitas dan kapabilitas disuatu bidang usaha tertentu atau tujuan tertentu sehingga dapat memperoleh hasil yang baik.

Tempat pemasaran hasil panen padi petani selain kepada Bulog, yaitu kepada tengkulak. Tengkulak adalah pedagang perantara (yang membeli hasil bumi dan sebagainya dari petani atau pemilik pertama), umumnya harga beli tengkulak lebih rendah daripada harga yang telah di tentukan oleh Bulog. Tengkulak memiliki beberapa fungsi yang sangat penting, yaitu sebagai tempat untuk memasarkan hasil pertanian. Tengkulak membeli hasil tanaman padi dari petani berupa gabah, kemudian menjual kembali kepada pedagang besar dibeberapa daerah. Biasanya tengkulak akan datang kerumah petani yang akan menjual gabahnya yang sudah dipanen dan masih dalam keadaan basah. Keberadaan tengkulak ini sudah mengakar dan sudah dikenal sejak dulu oleh petani. Menurut Scott (1993:7-8), hubungan atau ikatan patron klien merupakan kasus khusus dari hubungan diadik (dua orang atau dua pihak) yang melibatkan persahabatan instrumental antara seorang individu atau pihak dengan status sosio-ekonomi yang lebih tinggi (patron) yang menggunakan pengaruh dan sumberdayanya untuk menyediakan perlindungan dan atau keuntungan-keuntungan bagi seseorang dengan status lebih rendah (klien). Pada gilirannya, klien membalas dengan menawarkan dukungan umum dan bantuan kepada patron.

Selain ke Bulog dan tengkulak, ada pula pasar. Pasar yang merupakan tempat usaha untuk menjual barang, jasa dan tenaga kerja untuk orang-orang dengan imbalan uang. Pasar yang dimaksud disini adalah pedagang kiosnya. Pedagang kios mengambil harga lebih tinggi daripada tengkulak. Dalam proses penjualannya, petani dan pedagang kios akan melakukan kesepakatan harga sesuai dengan harga yang berlaku dipasar. Pedagang kios akan datang kerumah petani untuk mengambil gabahnya. Pedagang kios merupakan pelaku (agen) dalam proses pembelian gabah dari petani. Dalam teori strukturasi, agen yaitu orang-orang atau individu-individu yang melakukan tindakan secara terus menerus dan peristiwa didalam praktik sosial. (Gidden, 1995:4).

Dari hasil pengamatan peneliti, penjualan gabah di Desa Sumur Mati berbeda dengan desa lain, kebanyakan di desa lain menjual gabah mereka hanya kepada tengkulak. Sedangkan di Desa Sumur Mati ini penjualan gabah dilakukan pasca panen dan petani tidak hanya menjual kepada tengkulak. Petani di Desa Sumur Mati Kecamatan Sumberasih Kabupaten Probolinggo dalam menjual gabah ada yang menjual ke Bulog, ada yang menjual ke tengkulak, dan ada juga yang menjual kepada pedagang kios pasar.

Berdasarkan latar belakang di atas maka permasalahan dalam penelitian ini yaitu, bagaimana preferensi petani dalam penjualan gabah pasca panen di Desa Sumur Mati Kecamatan Sumberasih Kabupaten Probolinggo dan bagaimana hubungan kerja antara petani dengan Perum Bulog, petani dengan tengkulak, dan petani dengan pedagang kios.

\section{METODE PENELITIAN}

Jenis penelitian ini merupakan penelitian deskriptif dengan pendekatan kualitatif. Metode penentuan lokasi penelitian menggunakan metode purposive area yaitu di Desa Sumur Mati Kecamatan Sumberasih Kabupaten Probolinggo. Informan utama dalam penelitian ini berjumlah 12 orang petani padi, dengan kriteria pernah melakukan penjualan gabah lebih dari 5 kali. Informan utama terdiri dari 4 orang petani yang menjual ke tengkulak, 4 orang petani 
yang menjual ke Bulog, dan 4 orang petani yang menjual ke pedagang kios. Sedangkan yang dijadikan informan tambahan dalam penelitian ini adalah Pegawai Bulog, Tengkulak, dan Pedagang Kios. Metode pengumpulan data yang digunakan terdiri dari metode: wawancara, observasi, dan dokumen. Analisis data yang digunakan adalah analisis deskriptif yang meliputi reduksi data, penyajian data, dan penarikan kesimpulan (verifikasi).

\section{HASIL DAN PEMBAHASAN}

\section{Hasil Penelitian}

Preferensi petani di Desa Sumur Mati diketahui bahwa pola pikir petani didasari dari pengamalan yang diperoleh dan kepercayaan turun menurun. Petani di Desa Sumur Mati menjual kepada Perum Bulog karena ingin menambah pengamalan dan juga karena diarahkan oleh Babinsa untuk menjual gabah kepada Perum Bulog. Namun penjualan gabah petani kepda Perum Bulog hanya dilakukan dalam 3 kali jual atau 3 kali panen saja. Dari hasil penelitian yang telah dilakukan, petani berhenti menjual gabah mereka kepada Perum Bulog karena pengalaman yang petani peroleh selama menjual kepada Perum Bulog kurang baik. Sesuai dengan hasil wawancara yang dilakukan oleh peneliti terhadap subjek penelitian sebagai berikut.

"iya mbakjual ke Bulog, ya awalnya karena digiring oleh Babinsa mbak. Tapi ya nggak lama mbak soalnya ya hasilnya selalu rugi mbak. Jadi daripada rugi terus ya udah berhenti mbak. (Sholeh, $47^{\text {th }}$ )

Petani menjual kepada tengkulak karena sudah menjadi kebiasaan petani di Desa Sumur Mati atau bisa di sebut sudah langganan. Dari hasil penelitian diketahui bahwa petani menjual kepada tengkulak karena pengalaman yang telah diperoleh, petani sudah menjual gabah kepada tengkulak berulang-ulang sehingga petani meneruskan menjual gabah mereka kepada tengkulak. Selama ini, pengalaman yang diperoleh oleh petani selalu baik atau petani masih merasa untung dengan menjual kepada tengkulak. Berikut salah satu hasil wawancara peneliti dengan subjek penelitian.

"iya mbak sudah terbiasa jual ke tengkulak, ya bisa dibilang sudah langganan mbak, sudah dari dulu jual ke tengkulak mbak. Saya dengan tengkulak juga udah kenal baik mbak." (Fadil, 49 ${ }^{\text {th }}$ )

Petani yang menjual kepada pedagang kios juga sama halnya dengan teori preferensi yang terbentuk atas dasar pengalaman yang diperoleh dan kepercayaan turun temurun. Petani menjual kepada pedagang kios karena pengalaman yang diperoleh petani selama menjual gabah mereka. Diketahui dari hasil penelitian bahwa petani melakukan penjualan gabah tidak hanya sekali namun berulang kali. Sesuai dengan hasil wawancara peneliti dengan subjek penelitian.

"jual ke pedagang kios karena sudah lama jual kesana mbak. Dan juga karena sudah dipesan gitu mbak. Lagian selama ini jual ke pedagang kios juga enak mbak, untung dan nggak ribet jadi ya jualnya ke pedagang kios terus mbak." (Slamet, 40 $0^{\text {th }}$ )

Dari hasil wawancara diatas diketahui bahwa petani menjual gabah mereka kepada Bulog, kepada tengkulak dan kepada pedagang kios karena pengalaman yang mereka peroleh. 
Begitu juga saat petani berhenti menjual gabah kepada Bulog karena pengalaman yang mereka peroleh kurang baik.

Hubungan Bulog dengan Petani

Saat musim panen tiba, petani akan menjual hasil tanaman padinya. Petani padi di Desa Sumur Mati Kecamatan Sumberasih yang tergabung dalam kelompok tani pernah menjual hasil tanaman padi mereka kepada Bulog. Gapoktan di Desa Sumur Mati terdiri dari 4 kelompok tani, gapoktan ini yang pernah melakukan kemitraan dengan Bulog. Kemitraan yang dilakukan oleh Gapoktan Sumur Mati Kecamatan Sumberasih yaitu mengadakan penjualan gabah mereka kepada Perum Bulog Subdivre Probolinggo sesuai dengan kesepakatan yang telah di tentukan. Gapoktan Desa Sumur Mati digiring oleh Babinsa Sumberasih untuk mengadakan kemitraan dengan Perum Bulog Subdivre Probolinggo. Ketua Gapoktan mengarahkan anggotanya untuk mengadakan kemitraan. Petani Desa Sumur Mati yang bergabung dalam kelompok tani menjual hasil panen mereka kepada Bulog. Namun hanya beberapa kali saja mereka mengadakan penjualan kepada Bulog dan tidak diteruskan sampai sekarang. Kemitraan Bulog dengan kelompok tani Desa Sumur Mati tidak berlangsung lama dikarenakan petani merasa kesulitan dalam proses pengangkutan gabah dari Desa Sumur Mati ke gudang Bulog Subdrive Probolinggo. Berikut merupakan hasil wawancara dengan ketua Gapoktan Desa Sumur Mati yang menjadi subjek dalam penelitian ini:

"iya mbak, dulu pernah bermitra dengan Bulog tp nggak lama mbak. Ya gitu, kami merasa rugi dan tambah repot mbak. Kami yang harus nganter gabah kami ke Perum Bulog dan untuk pencairan uangnya harus ke bank dulu mbak, jadi ruwet mbak." (Sholeh, 47th)

Berdasarkan pendapat tersebut petani merasa kurang efisien dalam proses penjualan gabah. Petani harus mengantarkan gabah mereka ke Gudang Bulog dengan biaya ditanggung oleh petani, sehingga petani malah menderita kerugian. Setelah mengantarkan gabah ke Gudang Bulog, petani tidak langsung menerima uang hasil penjualannya. Petani harus mengurus terlebih dahulu ke kantor perum Bulog Subdrive probolinggo dan pencairan uang petani di ambil di Bank. Alasan itu menjadikan petani menghentikan hubungan kemitraan dengan Perum Bulog. Perhatian Bulog terhadap petani mempengruhi hubungan kerjasama antara petani dengan Bulog. Berikut merupakan hasil wawancara dengan subjek dalam penelitian ini.

"Iya mbak dulu pernah jual ke Bulog tapi sekarang sudah enggak mbak. Dulu jual ke Bulog karena diminta sama Babinsa sini mbak untuk nyoba jual ke Bulog, tapi ya rugi terus mbak. Proses penjualan ke Bulog susah mbak, lagian dari pihak Bulog nggak ada yang pernah kesini langsung mbak. Nggak pernah mengadakan sosialisasi dengan kelompok tani juga. Jadi petani sini lebih memilih untuk tidak jual ke Bulog lagi mbak. (Toli Saeri, 37th)."

Berdasarkan pendapat tersebut bahwa komunikasi Bulog dengan petani itu penting agar hubungan kerjasama dapat berjalan dengan baik. Kemitraan dapat berjalan dengan baik dan terus menerus jika diantara dua belah pihak saling menguntungkan. Perum Bulog mengadakan sosialisasi namun tidak perdesa melainkan mengumpulkan ketua Gapoktan dari tiap desa. Dari pihak Bulog tidak memberikan bantuan modal atau pun alat pertanian. Kendala-kendala yang menyebabkan terputusnya hubungan kemitraan antara perum Bulog dengan petani disebabkan 
oleh kurangnya keefisienan dari pihak Bulog untuk petani. Dari hasil penelitian di Desa Sumur Mati petani memilih untuk tidak melanjutkan kemitraan karena petani mengalami kerugian.

\section{Hubungan Tengkulak dengan Petani}

Hubungan tengkulak dengan petani merupakan pertukaran hubungan yang dapat dinyatakan sebagai kasus dari ikatan yang melibatkan persahabatan instrumental dimana seorang tengkulak dengan status sosio-ekonominya yang lebih tinggi (patron) menggunakan pengaruh dan sumber daya petani dengan status yang dianggapnya lebih rendah (klien). Patron Klien pada hubungan antara tengkulak dan petani padi di Desa Sumur Mati Kecamatan Sumberasih tersebut dapat dilihat dari pihak tengkulak yang sering memberikan bantuan serta memberikan pinjaman kepada petani guna memenuhi kebutuhan petani pada musim tanam atau saat petani membutuhkan modal dalam perawatan tanaman padinya. Berikut merupakan subjek dalam penelitian ini.

"Saya biasanya menjual gabah saya kepada tengkulak mbak, karena prosesnya mudah dan pencairan uangnya cepat. Dan juga karena saya biasanya sering meminjam uang kepada tengkulak saat kekurangan modal. Meminjam kepada tengkulak tanpa bunga mbak hanya saja hasil gabah saya harus dijual kepada tengkulak itu” (Fadil, 49 ${ }^{\text {th }}$ ).

Berdasarkan pendapat tersebut dapat diketahui bahwa banyak petani yang menjual kepada tengkulak karena prosesnya yang mudah dan terikat hutang dengan tengkulak. Dapat diketahui juga bahwa banyak diantara tengkulak yang beroperasi di Desa Sumur Mati Kecamatan Sumberasih yang memberikan pinjaman tanpa bunga namun dengan jaminan bahwa hasil tanaman padi dimusim panen nanti harus dijual kepada tengkulak tersebut sehingga petani menjadi terikat. Berikut merupakan penjelasan subjek dalam penelitian ini.

"Saya biasanya menjual gabah saya kepada tengkulak dek karena prosesnya cepat dan terkadang karna saya punya hutang kepada tengkulak itu dek jadi hasil panen saya harus dijual kepada tengkulak itu dek. Saya meminjam kepada tengkulak untuk memenuhi kekurangan modal dek dan pinjam kepada tengkulak itu enak soalnya tanpa bunga" (H. Abut, 48 ${ }^{\text {th }}$ ).

Pada musim panen seperti yang dijelaskan diatas, petani membutuhkan tengkulak dalam penjualan hasil panen padinya dan juga petani lebih memilih menjual kepada tengkulak karena prosesnya cepat dan uangnya cepat cair. Pada musim tanam padi tiba petani (klien) membutuhkan modal untuk menanam padi dan modal perawatan tanaman padinya. Para tengkulak (patron) akan memberikan pinjaman kepada klien tanpa bunga, sehingga pada saat panen nanti klien akan menjual hasil panen tanaman padinya kepada patron tersebut. Selain itu hubungan patron klien ini juga dilatar belakangi oleh struktur sosial petani yang mana menempatkan posisi petani sebagai pihak yang terdominasi dan modal sosial yang kecil.

\section{Hubungan Pedagang Kios dengan Petani}

Pada musim panen tiba, petani menjual hasil panen padi mereka. Petani di Desa Sumur

Mati Kecamatan Sumberasih Kabupaten Probolinggo sebagian menjual hasil panen padi mereka kepada pedagang kios dipasar. Penjualan berupa gabah dan harga dibentuk oleh pedagang. Hubungan kerja antara pedagang kios dan petani merupakan hubungan antara agen 
dan aktor dalam teori strukturasi Gidden. Pedagang yang merupakan agen melakukan pembelian gabah secara terus menerus dari petani. Berikut merupakan hasil wawancara dengan petani Desa Sumur Mati yang menjadi subjek dalam penelitian ini.

"Iya mbak saya menjual kepada pedagang pasar, biasanya harga ngikutin apa kata pedagang mbak tapi kami ya juga banyak untungnya. Udah biasa jual ke pedagang kios ini mbak. Biasanya tak telfon nanti pedagang kiosnya kesini mbak. Hasil gabah saya juga nggak terlalu banyak juga mbak. Untuk pembayaran kadang langsung, kadang dicicil mbak (Slamet, $40^{\text {th }}$ ).

Berdasarkan pendapat tersebut diketahui bahwa penjualan kepada pedagang kios harga lebih tinggi meskipun yang menentukan harga pedagang kios itu sendiri. Meski pembayarannya terkadang nyicil namun petani tetap percaya kepada pedagang kios dan biasanya tidak lama untuk melunasinya. Berikut merupakan hasil wawancara dengan salah satu petani Desa Sumur Mati yang menjadi subjek dalam penelitian ini.

"Iya mbak saya jual ke pedagang kios yang dipasar-pasar itu mbak. Awalnya ya karena udah kenal dan akhirnya jual kesitu mbak. Gabah saya nggak terlalu banyak mbak jadi ya jual ke pedagang kios pasar itu enak mbak. Biasanya ya ditelfon nanti kesini ngambil mbak. Pembayarannya biasanya tunai mbak tp ya kadang nyicil juga mbak tapi nggak lama mesti dilunasi mbak (Herman, 42 ${ }^{\text {th }}$ )."

Berdasarkan pendapat tersebut dapat diketahui bahwa petani yang memiliki sawah tidak terlalu luas dan hasil panen gabah tidak terlalu banyak menjual kepada pedagang kios pasar. Meski harga ditentukan oleh pedagang kios namun harga masih lebih tinggi jika petani menjual gabah mereka ke yang lain. Dalam pembayaran ini terkadang pedagang kios menyicil namun biasanya langsung dibayar tunai. Hubungan jual beli antara pedagang kios dan petani ini dilakukan secara terus menerus jika hasil gabah petani semakin baik. Hubungan petani dengan pedagang pasar dalam transaksi penjualan terjalin dengan baik. Jika hasil gabah petani baik biasanya pedagang kios akan memesan untuk panen musim depan dengan demikian maka praktik sosial terjadi berulang-ulang. Dengan adanya praktik sosial yang berulang-ulang tersebut pedagang menentukan aturan dalam proses pembelian dan pembayaran.

\section{Pembahasan}

Preferensi petani di Desa Sumur Mati diketahui bahwa pola pikir petani didasari dari pengamalan yang diperoleh dan kepercayaan turun menurun. Dimana Preferensi petani di Desa Sumur Mati dalam menjual gabah hasil panen meliputi bulog, tengkulak, dan pedagang kios. Dimana penjualan gabah hasil panen meliputi bulog, tengkulak, dan pedagang kios memiliki kelebihan dan kekurangan, seperti pada tabel sebagai berikut:

Tabel 1. Kelebihan dan Kekurangan Perum Bulog, Tengkulak, dan Pedagang Kios

\begin{tabular}{|c|c|c|}
\hline Perum Bulog & Tengkulak & Pedagang Kios \\
\hline $\begin{array}{l}\text { Kelebihan : } \\
\text { Harga sesuai dengan HPP } \\
\text { Adanya pembinaan untuk } \\
\text { petani mengenai cara tanam } \\
\text { padi }\end{array}$ & $\begin{array}{l}\text { Kelebihan : } \\
\text { Proses penjualan yang } \\
\text { cepat } \\
\text { Mudah berkomunikasi }\end{array}$ & $\begin{array}{l}\text { Kelebihan : } \\
\text { Harga yang diberikan lebih } \\
\text { tinggi } \\
\text { Proses penjualan cepat } \\
\text { Mudah berkomunikasi }\end{array}$ \\
\hline
\end{tabular}


Jurnal Pendidikan Ekonomi: Jurnal Ilmiah Ilmu Pendidikan, Ilmu Ekonomi, dan Ilmu Sosial \begin{tabular}{l|l|l} 
ISSN 1907-9990 & E-ISSN 2548-7175 & Volume 11 Nomor 1 (2017)
\end{tabular}

\begin{tabular}{|c|c|c|}
\hline Perum Bulog & Tengkulak & Pedagang Kios \\
\hline $\begin{array}{l}\text { Kekurangan : } \\
\text { Proses penjualan yang rumit } \\
\text { Adanya potongan harga jika } \\
\text { gabah petani tidak sesuai } \\
\text { dengan persyaratan }\end{array}$ & $\begin{array}{l}\text { Adanya bantuan } \\
\text { pinjaman modal untuk } \\
\text { petani } \\
\text { Kekurangan : } \\
\text { Petani menjadi terikat } \\
\text { dengan tengkulak }\end{array}$ & $\begin{array}{l}\text { Kekurangan : } \\
\text { Tidak adanya bantuan } \\
\text { pinjaman modal untuk } \\
\text { petani }\end{array}$ \\
\hline
\end{tabular}

Dari tabel di atas dapat diketahui bahwa adanya kelebihan dan kekurangan dari aktivitas penjualan gabah kepada Bulog, tengkulak, dan pedagang kios. Dari hasil penelitian yang telah dilakukan, petani yang melakukan kemitraan dengan Bulog tidak merasakan adanya keuntungan justru petani merasa rugi. Dengan menjual kepada Bulog seharusnya petani mendapatkan keuntungan lebih dengan harga yang sesuai dengan HPP. Namun selama petani menjual gabah kepada Bulog, harga yang diterima petani malah rendah. Ini disebabkan oleh gabah petani tidak sesuai dengan persyaratan Bulog sehingga Bulog memotong harga gabah petani.

Berdasarkan hasil penelitian yang telah dilakukan, kurangnya pengetahuan petani di Desa Sumur Mati dalam bercocok tanam padi membuat petani belum bisa menghasilkan gabah yang berkualitas baik. Selama ini ilmu percocok tanam hanya didapat secara turun temurun sehingga petani belum bisa meningkatkan kualitas gabah mereka. Petani di Desa Sumur Mati mengharapkan dengan menjadi mitra kerja Bulog, petani akan mendapatkan pembinaan langsung mengenai cocok tanam padi dan cara meningkatkan kualitas gabah mereka. Namun selama menjadi mitra kerja, petani tidak mendapatkan pembinaan dari Bulog. Sehingga gabah yang dihasilkan oleh petani dibawah kualitas gabah Bulog.

Kendala lain yang dirasakan oleh petani yaitu mengenai proses pengangkutan. Dimana pengangkutan gabah petani dari Desa Sumur Mati ke gudang Bulog dilakukan oleh petani dan biaya pengangkutan ditanggung oleh petani sehingga petani harus mengeluarkan biaya tambahan. Petani merasa kurang efisien dalam penjualan gabah kepada Perum Bulog. Selain itu dalam pencairan uang petani harus mencairkan melalui bank. Petani yang mengantarkan gabah ke gudang Bulog akan dicek terlebih dahulu, setelah itu petani akan mendapatkan surat pengantar dari gudang untuk ke kantor Perum Bulog Subdrive Probolinggo dan dari pihak kantor akan membuatkan cek untuk pencairan uang di bank. Proses ini yang dirasa petani cukup rumit. Dan alasan ini juga yang membuat petani berhenti menjadi mitra kerja Bulog.

Dari hasil penelitian yang telah dilakukan, petani menjual gabah kepada Bulog dan bermitra dengan Bulog karena digiring oleh Babinsa. Petani merasa hubungan kemitraan ini terjalin karena paksaan dari Babinsa. Hubungan koersif merupakan hubungan yang dilakukan karena adanya paksaan. Karena hubungan yang terjalin karena paksaan ini petani tidak pernah ada upaya untuk meningkatkan kualitas gabah petani. Ditambah lagi dengan kendala-kendala lain yang membuat petani merasa rugi sehingga petani menghentikan kemitraan dengan Bulog.

Aktivitas penjualan gabah petani kepada tengkulak terjalin cukup lama. Berdasarkan hasil penelitian yang telah dilakukan, petani menjual kepada tengkulak karena proses penjualan yang mudah. Selain itu juga karena petani sudah terbiasa menjual gabah kepada tengkulak. Dalam penjualan gabah kepada tengkulak, petani hanya menelfon tengkulak untuk datang 
kerumahnya. Tengkulak akan datang kerumah petani untuk menimbang dan pengangkutan gabah sehingga petani tidak perlu mengeluarkan biaya pengangkutan. Dalam pembayaran, tengkulak akan membayar uang secara tunai saat itu juga. Selain itu, petani yang menjual kepada tengkulak juga karena petani memiliki hutang sehingga petani harus menjual gabah mereka kepada tengkulak tersebut. Saat petani mengalami kesulitan modal atau saat petani membutuhkan uang mendesak, tengkulak akan memberikan pinjaman kepada petani dan tanpa bunga hanya saja pada saat panen petani harus menjual gabah mereka kepada tengkulak tersebut. Keadaan atau hubungan petani dengan tengkulak ini terjalin dalam suatu bentuk ikatan patron klien.

Berdasarkan penelitian yang telah dilakukan, ditemukan fakta bahwa dalam hubungan patron klien antara tengkulak dan petani di Desa Sumur Mati Kecamatan Sumberasih Kabupaten Probolinggo menunjukkan kondisi yang terkadang kurang seimbang. Dimana petani yang sudah terikat hutang harus menjual gabah mereka kepada tengkulak tersebut dan harga pembelian gabah di tentukan oleh tengkulak. Sehingga petani mengikuti harga dari tengkulak.

Hubungan patron klien antara tengkulak dan petani di Desa Sumur Mati Kecamatan Sumberasih Kabupaten Probolinggo juga dapat terbangun dengan utuh karena terpeliharanya rasa saling percaya satu sama lain. Rasa saling percaya terlibat dalam hal tengkulak memberikan pinjaman kepada petani saat mengalami kesulitan permodalan. Setiap kesulitan permodalan petani akan langsung datang ke tengkulak. Hal ini sesuai dengan yang dikemukan oleh Scott (dalam Suprihatin, 2002. 150-151), sifat tatap muka memberikan makna bahwa hubungan patron klien adalah hubungan pribadi, yaitu hubungan yang didasari rasa saling percaya. Masing-masing pihak mengandalkan penuh pada kepercayaan, karena hubungan ini tidak disertai perjanjian tertulis.

Berdasarkan observasi yang dilakukan dapat diketahui bahwa antara petani dengan pedagang kios di pasar terdapat interaksi yang cukup baik. Hal tersebut dapat dilihat bahwa para petani menjual hasil panen berupa gabah kepada pedagang maupun kios-kios di pasar secara berkelanjutan (terus menerus). Hal ini membuktikan bahwa antara petani dengan para pedagang kios di pasar telah terjalin suatu kesepakatan tidak tertulis yang menyebabkan mereka memiliki ikatan secara tidak langsung berkaitan dengan jual beli hasil panen petani tersebut.

Hubungan kerja antara pedagang kios dan petani merupakan hubungan antara agen dan aktor seperti pada teori strukturasi Giddens. Menurut Giddens (dalam Ritzer dan Goodman, 2004:508), praktik atau tindakan manusia dapat dilihat sebagai perulangan yaitu aktivitas bukanlah dihasilkan sekali jadi oleh aktor sosial, tetapi secara terus menerus. Dimana hubungan jual beli antara pedagang kios dengan petani dalam penelitian ini juga terjadi secara terus menerus dan didalamnya terdapat praktik sosial. Dalam hal ini pedagang kios merupakan agen dalam teori strukturasi. Agen yaitu orang-orang atau individu-individu yang melakukan tindakan secara terus menerus dan peristiwa didalam praktik sosial. (Gidden, 1995:4).

Pedagang kios sebagai agen melakukan pembelian hasil panen secara terus-menerus dari petani karena adanya suatu simbiosis mutualisme antara petani dengan pedagang kios tersebut. Pedagang akan memperoleh keuntungan dengan melakukan pembelian gabah kepada petani langsung, yaitu lebih cepat dan dengan harga yang lebih murah daripada harus membeli pada bulog. Selain itu, dengan membeli gabah dari petani langsung akan lebih efisien. Begitu halnya pada petani, para petani merasa lebih menguntungan (terutama petani yang tidak 
memiliki sawah terlalu luas), karena dengan menjual kepada pedagang kios petani akan merasa aman saat adanya pesanan dari pedagang kios yang akan membeli hasil panen gabah di musim panen yang akan datang.

Pedagang kios di pasar yang melakukan pembelian gabah menentukan harga pembelian dan proses pembayaran. Pedagang akan menentukan harga pembelian yang sesuai dengan pasaran, namun harga yang diberikan oleh pedagang kios pasar tidak banyak merugikan petani. Pembayaran ditentukan oleh pedagang kios pasar, terkadang dibayar tunai dan terkadang dibayar cicil. Namun meski dicicil petani akan merasa aman dan percaya karena pedagang kios pasar pasti melunasi pembayaran. Meski dicicil namun pedagang kios tidak pernah lama dalam waktu melunasinya. Dalam menjual gabah kepada pedagang kios ini, petani tidak mendapat bantuan pinjaman modal.

\section{KESIMPULAN DAN SARAN \\ Kesimpulan}

Berdasarkan penelitian yang telah dilakukan dapat disimpulkan bahwa Hasil penelitian menunjukkan bahwa petani di Desa Sumur Mati menjual gabah kepada Perum Bulog, tengkulak, dan pedagang kios pasar. Dari segi hubungan Bulog dengan petani, petani menjual kepada Bulog karena digiring oleh Babinsa. Penjualan gabah kepada Bulog dilakukan karena petani merasa terpaksa sehingga petani tidak berupaya untuk melakukan lebih baik lagi. Dalam kemitraan petani dengan Bulog juga terdapat kendala-kendala yang merugikan petani. Karena awalnya petani terpaksa dan akhirnya petani selalu merasa rugi maka petani tidak melanjutkan kemitraan dengan Bulog.

Hubungan tengkulak dengan petani terjalin dengan baik dan dalam ikatan patron klien. Tengkulak sebagai patron berada pada posisi pemegang modal besar sehingga tengkulak dapat memberikan pinjaman modal kepada petani sebagai jaminan agar petani menjual gabah kepada tengkulak tersebut. Sedangkan petani berada pada pihak klien dimana petani memiliki modal yang rendah. Petani memilih menjual kepada tengkulak karena petani sudah terikat dengan tengkulak. Selain itu dalam proses penjualan gabah ini petani merasa mudah dan uangnya dibayar secara tunai saat menjual gabah tersebut.

Hubungan pedagang kios dengan petani terjalin dengan baik dan hubungan kontraktual. Dimana pedagang kios dan petani melakukan perjanjian lisan jual beli gabah. Petani tidak mendapatkan pinjaman modal dari pedagang kios namun petani mendapatkan harga yang lebih tinggi daripada petani menjual kepada yang lain. Hubungan pedagang kios dengan petani hanya sebatas jual beli gabah saja.

\section{Saran}

Berdasarkan kesimpulan di atas dari penelitian ini, maka peneliti ingin memberikan saran yaitu bagi petani di Desa Sumur Mati Kecamatan Sumberasih Kabupaten Probolinggo dapat meningkatkan kemampuan dalam menanam padi dan merawat tanaman padi sehingga dapat meningkatkan kualitas gabah dan mendapatkan harga yang lebih dan meningkatkan keuntungan. Dan bagi Perum Bulog untuk terus melanjutkan hubungan kemitraan dengan mitra kerja yang baik diperlukan perhatian dan pelayanan terhadap mitra kerja. Sehingga mitra kerja dapat merasakan keuntungan dari hubungan kemitraan tersebut. 


\section{DAFTAR BACAAN}

Gidden, Anthony. 1995. The Constitution of Society "Teori Strukturasi untuk Analisis Sosial. Pasuruan: Penerbit Pedati.

Instruksi Presiden Republik Indonesia Nomor 5 Tahun 2015 tentang Kebijakan Pengadaan Gabah/Beras dan Penyaluran Beras Oleh Pemerintah.

Peraturan Pemerintah Republik Indonesia Nomor 44 Tahun 1997 tentang Kemitraan.

Ritzer, George \& Goodman Douglas J. 2004. Teori Sosiologi Modern. Jakarta: Kencana Prenada Media Grup.

Scott, James C. 1993. Perlawanan Kaum Tani. Jakarta: Yayasan Obor. Edisi Pertama.

Sulistiyani, Ambar Teguh. 2004. Kemitraan dan Model-Model Pemberdayaan. Yogyakarta: Gava Media.

Suprihatin, S. 2002. "Hubungan Patron Klien Pedagang "Nasi Kucing” Di Kota Yogyakarta”. Jurnal Sosiohumanika. 